

\title{
Kronisk utmattelse setter avtrykk i immunforsvaret
}

FRA ANDRE TIDSSKRIFTER

RUTH HALSNE

Tidsskriftet

Cytokinnivåene hos pasienter med kronisk utmattelsessyndrom gjenspeiler sykdommens alvorlighetsgrad, ifølge ny studie.

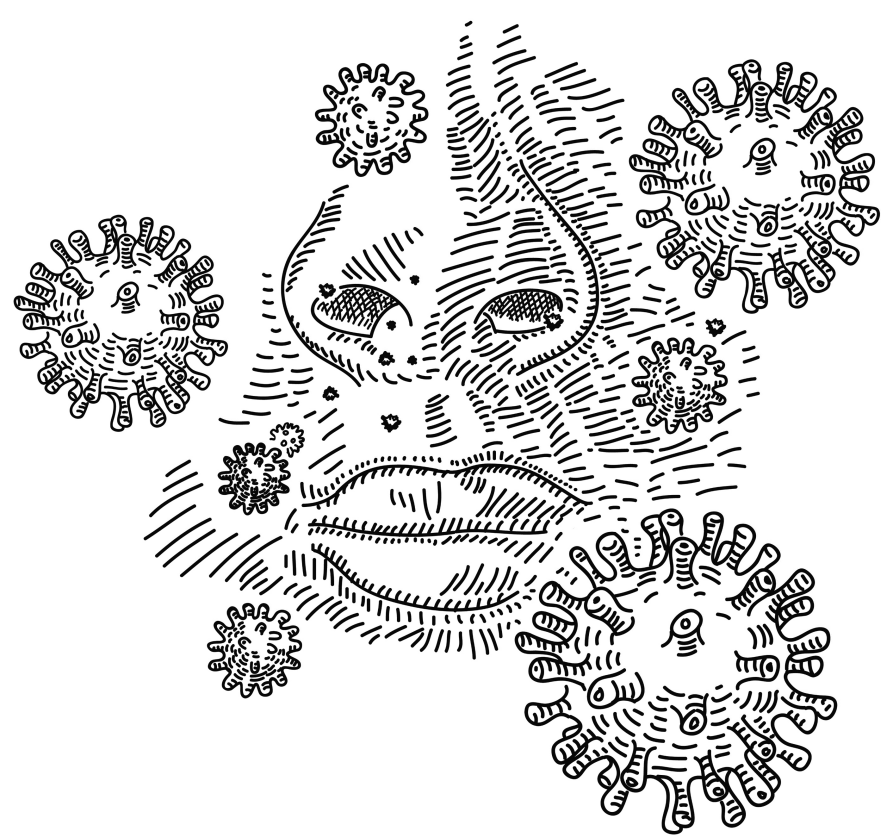

Illustrasjon: iStock

Mange pasienter med kronisk utmattelsessyndrom (ME/CFS) rapporterer om influensalignende symptomer. I en ny studie ble cytokinnivåer i serum målt hos 192 pasienter og 392 friske kontrollpersoner (1). Målingene ble gjort med et «highthroughput»-system med bruk av kuler med antistoffer spesifikt rettet mot 51 forskjellige cytokiner. Antistoffene ble merket med fluoriserende farger, slik at mengde og type cytokiner ble registrert etter bestråling fra en laserkilde.

Det ble funnet svært små forskjeller mellom pasientgruppen og kontrollgruppen, men i pasientgruppen korrelerte nivåene av 17 cytokiner med alvorlighetsgrad og sykdomsvarighet. 13 av disse cytokinene er knyttet til inflammasjon og antas å kunne bidra 
til pasientenes symptomer.

- Studier av cytokinendringer har til nå gitt få entydige svar om hva som faktisk skjer hos pasienter med kronisk utmattelsessyndrom, sier Karl Johan Tronstad, som er professor ved Institutt for biomedisin, Universitetet i Bergen. Dette kan ha sammenheng med at det er stor variasjon innad i pasientgruppen hva gjelder sykdomsvarighet, alvorlighetsgrad og dagsform, sier han.

- I tidligere studier er cytokinendringer satt i sammenheng med sykdomsvarighet, men i denne studien kan slike endringer synes å være koblet til sykdommens alvorlighetsgrad, sier Tronstad.

De aktuelle cytokinene er kjent for å påvirke en rekke biologiske mekanismer, deriblant energistoffskiftet, noe som kan bidra til å forklare deler av det kliniske symptombildet.

- Funnene i denne studien taler for at det kan være viktig med subgruppering av pasienter med kronisk utmattelsessyndrom for å finne frem til best mulig behandling. Studien styrker teorien om at tilstanden er forbundet med systemiske inflammasjonsprosesser og endringer i immunsystemet og gir dermed støtte til hypotesen at immunmodulerende behandling kan ha effekt hos pasienter med kronisk utmattelsessyndrom, sier Tronstad.

\section{LITTERATUR:}

1. Montoya JG, Holmes TH, Anderson JN et al. Cytokine signature associated with disease severity in chronic fatigue syndrome patients. Proc Natl Acad Sci U S A 2017; 114: E7150 - 8. [PubMed][CrossRef]

Publisert:30. oktober 2017. Tidsskr Nor Legeforen. DOI:10.4045/tidsskr.17.0752

(C) Tidsskrift for Den norske legeforening 2020. Lastet ned fra tidsskriftet.no 